\title{
MEDIA PEMBELAJARAN DAN UPAYA MEMBANGUN KESADARAN BELAJAR SISWA
}

\author{
Abusiri \\ Sekolah Tinggi Agama Islam ALHIKMAH Jakarta \\ Abusiri2014@gmail.com
}

\section{Abstract}

Teaching and learning process is essentially a communication process and message delivery from the presenter to the recipient. This message is delivered in verbal and non verbal communication. Instructional media play a role to support the delivery of learning message to be more standardized, interesting, effective, and efficcient. This can be done by utilizing the development of information communication technology that provides widespread opportunities in education in order to improve the educational quality. Using technology as an instructional media can make the learning process more fun and ease the comprehension, so that, the student learning awareness will grow on their own.

Keywords: Instructional media, Information technology, Learning awareness 


\section{Abstrak}

Proses belajar mengajar pada hakikatnya merupakan proses komunikasi dan penyampaian pesan dari pengantar ke penerima. Pesan ini dituangkan dalam komunikasi verbal dan non verbal. Media pembelajaran berperan agar penyampaian pesan pembelajaran dapat lebih terstandar, menarik, efektif, dan efisien. Hal ini bisa dilakukan dengan memanfaatkan perkembangan teknologi informasi komunikasi yang memberikan kesempatan luas pada dunia pendidikan dalam meningkatkan mutu pendidikan. Memanfaatkan teknologi sebagai media pembelajaran membuat proses belajar dapat lebih menyenangkan dan pemahaman menjadi lebih mudah, sehingga dengan demikian kesadaran belajar siswa akan tumbuh dengan sendirinya.

Kata Kunci: Media pembelajaran,Teknologi informasi, Kesadaran belajar 


\section{A. PENDAHULUAN}

uru mengajar dan siswa belajar merupakan dua kegiatan
yang sinergi dalam kegiatan pembelajaran. Guru
mengajarkan bagimana siswa harus belajar, sementara siswa belajar bagaimana seharusnya belajar melalui berbagai pengalaman belajar hingga terjadi perubahan dalam dirinya dari aspek kognitif, psikomotorik, maupun afektif. Persoalannya bagaimana membangun kesadaran siswa agar secara sukarela mau dan senang belajar. Guru harus merancang kegiatan pembelajaran yang memungkinkan siswa melakukan belajar secara aktif, baik fisik maupun mental, hal ini menuntut kreativitas dan kemampuan guru dalam merancang dan melaksanakan kegiatan pembelajaran. Dalam melaksanakan kegiatan guru perlu memikirkan suatu strategi pembelajaran yang tepat, efektif, dan efisien. Begitu pula seorang guru dapat menggunakan media pembelajaran yang tepat dan sesuai dengan materi pembelajaran.

Perlunya media dalam pembelajaran, karena proses belajar mengajar hakikatnya adalah proses komunikasi dan penyampaian pesan dari pengantar ke penerima. Pesan ini dituangkan dalam komunikasi verbal (kata-kata dan tulisan) dan non verbal (gambar visual). Media pembelajaran sangat bermanfaat agar penyampaian pesan pembelajaran dapat lebih terstandar, pembelajaran dapat lebih menarik, meningkatkan interaktif siswa dalam menerapkan teori belajar, mempersingkat waktu pembelajaran dan kualitas pembelajaran dapat ditingkatkan. Perkembangan teknologi informasi komunikasi juga memberikan kesempatan yang luas pada dunia pendidikan dalam meningkatkan mutu pendidikan. Memanfaatkan teknologi membuat proses belajar dapat lebih menyenangkan dan pemahaman menjadi lebih mudah.

\section{B. PENGERTIAN, URGENSI DAN PERANAN MEDIA PEMBELAJARAN}

Secara bahasa kata media memiliki arti "perantara" atau "pengantar". Association for Education and Communcation 
Technology (AECT) mendefinisikan media yaitu segala bentuk yang dipergunakan untuk suatu proses penyaluran informasi. Sedangkan National Education Association (NEA) mendefinisikan media pembelajaran sebagai benda yang dapat dimanipulasikan, dilihat, didengar, dibaca, atau dibicarakan beserta instrumen yang dipergunakan dengan baik dalam kegiatan pembelajaran dan dapat mempengaruhi efektifitas program instruksional. ${ }^{1}$

Hakikat proses belajar-mengajar adalah proses komunikasi, maka salah satu faktor kegagalan pembelajaran adalah adanya berbagai jenis hambatan dalam proses komunikasi antara siswa dan guru karena variasi dalam pengajaran sertajarangnya digunakan alat bantu yang dapat memperjelas pemahaman siswa tentang materi yang dipelajari. Pemilihan media yang tepat menjadi penting agar transfer ilmu pengetahuan dari guru bisa maksimal, sehingga siswa tidak hanya mendengar apa yang disampikan oleh guru, tetapi juga melihat proses (penginderaan)-nya. ${ }^{2}$ Begitu pula dalam komunikasi sering timbul dan terjadi penyimpangan-penyimpangan sehingga komunikasi tersebut tidak efektif dan efisien, antaralain disebabkan oleh adanya verbalisme, ketidaksiapan siswa, kurangnya minat dan kegairahan, dan sebagainya.

Salah satu usaha untuk mengatasi keadaan demikian ialah penggunaan media secara terintegrasi dalam proses pembelajaran, karena fungsi media dalam kegiatan tersebut di samping sebagai penyaji stimulus informasi, sikap, dan lain-lain, juga untuk meningkatkan keserasian dalam penerimaan informasi. Dalam hal-hal tertentu media juga berfungsi untuk mengatur langkahlangkah kemajuan serta untuk memberikan umpan balik.

Semua bentuk sarana pendidikan disyaratkan mampu membantu peserta didik memahami bahan ajar yang diberikan tenaga pendidik kepadanya, disamping harus pula mampu membangkitkan minat belajar pada peserta didik tersebut. Sarana pendidikan sebagai media pendidikan harus mampu membangkitkan rangsangan indera penglihatan, pendengaran,

1 Asnawir dan Basyiruddin Usman, Media Pembelajaran (Jakarta: Ciputat Press, 2002), h. 11.

2 http://www.indopos.co.id/index.php. Download tanggal 04 Februari 2017. 
perabaan, pengecapan serta penciuman. Untuk tujuan tersebut maka seorang pendidik perlu memiliki sebuah media pembelajaran yang memadai, agar bahan ajar dapat diserap peserta didik dengan sebaik-baiknya.

Penggunaan media dalam proses pembelajaran mempunyai nilai-nilai praktis sebagai berikut: ${ }^{3}$

1. Media dapat mengatasi berbagai keterbatasan pengalaman yang dimiliki siswa.

2. Media dapat mengatasi ruang kelas, baik ruang yang terlalu besar, atau terlalu sempit.

3. Media memungkinkan adanya interaksi langsung antara siswa dengan lingkungan.

4. Media menghasilkan keseragaman pengamatan siswa.

5. Media dapat menanamkan konsep dasar yang benar, kongkrit, dan realistis. Penggunaan media, seperti: gambar, film, model, grafik, dan lainnya dapat memberikan konsep dasar yang benar.

6. Media dapat membangkitkan keinginan dan minat yang baru.

7. Media dapat membangkitkan motivasi dan merangsang siswa untuk belajar.

8. Media dapat memberikan pengalaman yang integral dari suatu yang konkrit sampai kepada yang abstrak.

Lebih lanjut Hamalik mengemukakan bahwa penggunaan media pembelajaran dalam proses pembelajaran dapat meningkatkan keinginan dan minat yang baru, membangkitkan motivasi dan rangsangan kegiatan belajar, dan bahkan membawa pengaruh-pengaruh psikologis terhadap siswa. Penggunaan media pembelajaran pada tahap orientasi pembelajaran akan sangat membantu keefektifan proses pembelajaran dan penyampaian pesan dan isi pelajaran pada saat itu. Selain membangkitkan motivasi dan minat siswa, media pembelajaran juga dapat membantu siswa meningkatkan pemahaman, menyajikan data dengan menarik dan terpercaya, memudahkan penafsiran data,

3 Asnawir dan Basyiruddi Usman, Media..., h. 14-15. 
dan memadatkan informasi. ${ }^{4}$ Sejalan dengan uraian ini, Mahmud Yunus dalam bukunya al-tarbiyah wa al-ta'lim mengungkapkan sebagai berikut:

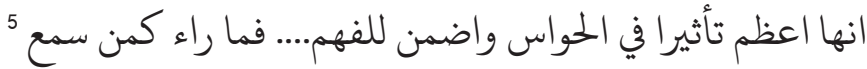

Maksudnya "media pembelajaran paling besar pengaruhnya bagi indera dan lebih dapat menjamin pemahaman...orang yang mendengarkan saja tidaklah sama tingkat pemahamannya dan lamanya bertahan apa yang dipahaminya dibandingkan dengan mereka yang melihat, melihat dan mendengarnya".

Levie \& Lentz sebagaimana dikutip oleh Azhar Arsyad mengemukakan empat fungsi media pembelajaran, khususnya media visual, yaitu: ${ }^{6}$

1. Fungsi atensi yaitu menarik dan mengarahkan perhatian siswa untuk berkonsentrasi pada isi pelajaran yang berkaitan dengan makna visual yang ditampilkan atau menyertai teks materi pelajaran. Seringkali siswa pada awal pelajaran tidak tertarik dengan materi pelajaran, sehingga sering tidak memperhatikan. Dengan gambar, misalnya melalui overhead projector dapat menenangkan dan mengarahkan perhatian siswa terhadap materi pelajaran yang akan mereka terima. Dengan demikian, kemungkinan untuk memperoleh dan mengingat isi pelajaran lebih besar.

2. Fungsi afektif, terlihat dari tingkat kenikmatan siswa ketika belajar teks yang bergambar. Gambar atau lambang visual dapat menggugah emosi dan sikap siswa, misalnya informasi yang menyangkut masalah sosial atau ras.

3. Fungsi kognitif, terlihat dari temuan-temuan penelitian yang mengungkapkan bahwa lambang visual atau gambar memperlancar pencapaian tujuan untuk memahami dan mengingat informasi atau pesan yang terkandung dalam gambar.

4 Oemar Hamalik, Media Pendidikan (Bandung: PT Citra Aditya, 1994), h. 19.

5 Mahmud Yunus, Al-Tarbiyah wa al-Ta'lim (Padang Panjang: Matbah, 1942), h. 78.

6 Azhar Arsyad, Media Pembelajaran, (Jakarta: PT Raja Grafindo Persada, 2007), h. 16-17. 
4. Fungsi kompensatoris, dari hasil penelitian bahwa media visual yang memberikan konteks untuk memahami teks membantu siswa yang lemah dalam membaca untuk mengorganisasikan informasi dalam teks dan mengingatnya kembali. Dengan kata lain, media pembelajaran berfungsi untuk mengakomodasikan siswa yang lemah dan lambat menerima dan memahami isi pelajaran yang disajikan dengan teks atau disajikan secara verbal.

Perlu disadari bahwa mutu pendidikan yang tinggi baru dapat dicapai jika proses pembelajaran yang diselenggarakan di kelas efektif dan fungsional bagi pencapaian kompetensi yang dimaksud. Oleh sebab itu usaha meningkatkan mutu pendidikan kejuruan tidak terlepas dari usaha memperbaiki proses pembelajaran. Proses pembelajaran merupakan aktivitas yang terdiri atas komponenkomponen yang bersifat sistemik. Artinya komponen-komponen dalam proses pembelajaran itu saling berkaitan secara fungsional dan secara bersama-sama menentukan optimalisasi proses dan hasil pembelajaran. Komponen-komponen pembelajaran tersebut menurut Mudhoffir dijabarkan atas pesan, orang, bahan, alat, teknik, dan lingkungan. Sedangkan menurut Winkel, komponen pembelajaran terdiri dari tujuan pembelajaran, kondisi awal, prosedur didaktik, pengelompokan siswa, materi, media, dan penilaian.

\section{KLASIFIKASI MEDIA PEMBELAJARAN}

Media belajar, dilihat dari alat indera yang dipergunakan dapat dibedakan menjadi media dengar (audio), media pandang (visual), dan media dengar pandang (audio visual) yang dapat dimanipulasi anak. ${ }^{7}$ Rudi Bretz sebagaiamana dikutip oleh Asnawir dan Basyiruddin Usman mengkalisifikasi ciri utama media pembelajaran pada tiga unsur pokok, yaitu suara, visual, dan gerak. Bentuk visual itu sendiri dibedakan lagi pada tiga bentuk, yaitu gambar visual, garis (linergraphic) dan simbol. Dia juga membedakan media siar

7 Siti Kusrini.dkk Ketrampilan Dasar Mengajar (PPL I) Berorientasi Pada Kurikulum Berbasis Kompetensi (Malang: Fakultas Tarbiyah Universitas Islam Negeri, 2005), h. 112. 
(transmisi) dan media rekam (recording), sehingga ada 8 klasifikasi media:

1. Media audio visual gerak, seperti televisi, gambar, film, pita suara, film TV, dan holografi.

2. Media audio visual diam, seperti slow scan TV, time shared TV, dan film rangkai.

3. Media audio visual semi gerak, seperti tulisan jauh, rekaman audio tulisan jauh, audio pointer.

4. Media visual gerak, seperti film bisu (pantomim).

5. Media visual diam, seperti facsimile, seri gambar, dan arsip video.

6. Media visual semi gerak, seperti teleugraph.

7. Media audio, seperti telepon radio.

8. Media cetak, seperti teletip. ${ }^{8}$

Dalam perkembangannya media pembelajaran mengikuti perkembangan teknologi. Teknologi yang paling tua yang dimanfaatkan dalam proses pembelajaran adalah percetakan yang bekerja atas dasar prinsip mekanis. Kemudian lahir teknologi audio visual yang menggabungkan penemuan mekanis dan elektronis untuk tujuan pembelajaran. Teknologi yang muncul Seperti teknologi mikroprosesor yang melahirkan pemakaian komputer dan kegiatan interaktif. Berdasarkan perkembangan teknologi tersebut, maka media pembelajaran dapat dibagi menjadi empat kelompok, yaitu: ${ }^{9}$

1. Teknologi cetak, adalah cara untuk menghasilkan atau menyampaikan materi, seperti buku dan materi visual statis terutama melalui proses pencetakan mekanis atau fotografis. Kelompok media hasil teknologi cetak meliputi teks, grafiks, foto, atau representasi fotografik dan reproduksi.

2. Teknologi audio visual, yaitu cara menghasilkan atau menyampaikan materi dengan menggunakan mesin-mesin mekanis dan elektronik untuk menyajikan pesan-pesan

8 Asnawir dan Basyiruddi Usman, Media..., h. 27.

9 Azhar Arsyad, Media..., h. 29. 
audio visual. Pengajaran melalui audio visual jelas bercirikan pemakaian perangkat keras selama proses belajar, seperti mesin proyektor film, tape recorder, dan proyektor visual yang lebar.

3. Teknologi berbasis komputer, merupakan cara menghasilkan atau menyampaikan materi dengan menggunakan sumbersumber yang berbasis mikroprosesor. Teknologi berbasis komputer menggunakan layar kaca untuk menyajikan informasi kepada siswa. Pembelajaran model seperti ini sering disebut dengan computer assisted instruction (pembelajaran dengan bantuan komputer).

4. Teknologi gabungan, adalah cara untuk menghasilkan dan menyampaikan materi yang menggabungkan pemakaian beberapa bentuk media yang dikendalikan oleh komputer. ${ }^{10}$

Nana Sudjana dan Ahmad Rivai secara sederhana membagi media pengajaran dilihat dari segi fungsi dan perananya dalam proses pembelajaran ke dalam kategori;(a) media grafis seperti gambar, foto, grafik, bagan, atau diagram, poster, kartun, komik, dan lain-lain, (b) media tiga dimensi yaitu dalam bentuk model, seperti model padat (solid model), model penampang, model susun, model kerja, mock up, diorama, dan lain-lain, (c) media proyeksi, seperti slide, film strips, film, penggunaan OHP, dan lain-lain, (d) Penggunaan lingkungan sebagai media pengajaran. ${ }^{11}$

\section{MULTIMEDIA DALAM PEMBELAJARAN}

Perkembangan teknologi informasi komunikasi memberikan kesempatan yang luas pada dunia pendidikan dalam meningkatkan mutu pendidikan. Memanfaatkan teknologi membuat proses belajar dapat lebih menyenangkan dan pemahaman menjadi lebih mudah. Dengan itu, melalui jaringan internet, sumber bahan belajar siswa dan ketersediaan informasi tidak terbatas pada guru

10 Azhar Arsyad, Media..., h. 32.

11 Nana Sudjana dan Ahmad Rivai, Media Pengajaran (Bandung: Sinar Baru Algesindo, 2005 ), h. 3-4. 
pembimbing maupun buku pelajaran di kelas. ${ }^{12}$

Sudahsaatnyapembelajarandisekolahmemberikankesempatan pada siswa untuk menerapkan kecakapan dan membangun pengetahuan mereka sendiri. Siswa dapat menggunakan berbagai jenis teknologi untuk melaksanakan riset, berkomunikasi dan menciptakan pengetahuan. Pendidikan berbasis teknologi telah menjadi pilihan untuk mempersiapkan manusia yang berkualitas di era globalisasi. Karena itu, sekolah harus segera mengaplikasikan teknologi informasi dan mengadopsi sistem pendidikan berbasis ICT dalam proses belajar mengajar.

Media yang cocok dengan maksimalisasi transfer ilmu pengetahuan dalam proses pembelajaran salah satunya adalah memanfaatkan teknologi audiovisual berbasis multimedia (teknologi yang melibatkan teks, gambar, suara, dan video). Multimedia secara bahasa adalah media yang lebih dari satu jenis. Menurut Rosch sebagaimana disampaikan oleh Ki Supriyoko dalam perkuliahannya multimedia adalah kombinasi dari komputer dengan video. Multimedia adalah kombinasi tiga elemen, yaitu suara, gambar, dan teks. Multimedia adalah kombinasi paling sedikit dua media input atau output data, media ini dapat berupa audio (suara, musik), animasi, video, teks, grafiks, dan gambar. ${ }^{13}$

Karakteristik pembelajaran multimedia adalah sebagai berikut: ${ }^{14}$

1. Memanfaatkan information technology.

2. nano technology

3. technological literacy

4. anywhere accesable

5. mass education

6. competitive material

7. many choices

Pemanfaatan komputer selain mengoptimalkan pembelajaran dengan tatap muka, memungkinkan pembelajaran tanpa tatap

12 http://www.equator-news.com/. Download tanggal 16 Februari 2017.

13 Materi kuliah yang disampaikan oleh Ki Supriyoko pada Mata Kuliah Teknologi Pendidikan Agama Islam pada tanggal 04 Maret 2017.

14 Ibid.

HIKMAH, Vol. XIII, No. 1, $2017 \sim 45$ 
muka. Misalnya, melalui CD interaktif, pembelajaran dilakukan tanpa harus tatap muka antara peserta didik dengan gurunya. Perkembangan teknologi komputer memungkinkan siswa berinteraksi dengan sumber belajar melalui internet. Sehingga siswa berkomunikasi dan bertukar informasi tanpa terbatas waktu dan ruang. ${ }^{15} \mathrm{Di}$ antara media pembelajaran yang berbasis multimedia adalah:

1. Microsoft Power Point

Perlu kita diketahui bahwa teknologi informasi telah mengalami perkembangan yang sangat pesat. Teknologi informasi harus disadari telah mampu membuat berbagai cara untuk mempermudah penyampaian informasi, seperti misalnya teknologi program Power Point. Merupakan suatu hal yang menarik untuk melakukan suatu percobaan dengan penggunaan media belajar program Power Point dalam pembelajaran. ${ }^{16}$

Microsoft Power Point merupakan salah satu aplikasi milik Microsoft, disamping Microsoft Word dan Microsoft Exel yang telah di kenal banyak orang. Ketiga aplikasi ini lazim disebut Microsoft Office. Pada dasarnya, aplikasi Microsoft Power Point berfungsi untuk membantu user dalam menyajikan persentasi. Aplikasi Power Point menyediakan fasilitas slide untuk menampung pokok-pokok pembicaraan yang akan disampaikan pada peserta didik. Dengan fasilitas animasi, suatu slide dapat dimodifikasi dengan menarik. Begitu juga dengan adanya fasilitas: front picture, sound dan effect dapat dipakai untuk membuat suatu slide yang bagus. Bila produk slide ini disajikan, maka para pendengar dapat ditarik perhatiannya untuk menerima apa yang kita sampaikan kepada peserta didik.

Kelebihan-kelebihan pembelajaran dengan Microsoft Power Point adalah sebagai berikut:

a. Dapat menstimulasi efek gerak.

b. Dapat diberi suara dan warna.

15 http://www.equator-news.com/. Download tanggal 14 Februari 2017.

16 mailto:butar_lbt@yahoo.co.id. Download tanggal 10 April 2017. 
c. Tidak memerlukan keahlian khusus dalam penyajian.

d. Tidak memerlukan ruang gelap dalam penyajian.

e. Pembelajaran lebih efektif dan efisien karena guru telah memilah bagian atau poin yang penting untuk disampaikan.

Selain memiliki kelebihan, beberapa kekurangan yang dimiliki oleh media pembelajaran dengan Microsoft Power Point, adalah sebagai berikut:

a. Memerlukan peralatan khusus dalam penyajian, yang dalam hal ini sekolah dituntut mempunyai peralatan teknologi yang digunakan untuk menyajikan pembelajaran dengan power point ini.

b. Memerlukan tenaga listrik dan hal ini akan menambah beban biaya pada sekolah.

c. Memerlukan keterampilan khusus dalam pembuatan, terutama bagi seorang guru yang belum mengenal power point, maka ia dituntut untuk mempelajari dan mengaplikasikan power point ini.

2. Macromedia Flash MX

Macromedia Flash MX merupakan gabungan konsep pembelajaran dengan teknologi audiovisual yang mampu menghasilkan fitur-fitur baru yang dapat dimanfaatkan dalam pendidikan. Pembelajaran berbasis multimedia dapat menyajikan materi pelajaran yang lebih menarik, tidak monoton, dan memudahkan penyampaian. Siswa dapat mempelajari materi pelajaran tertentu secara mandiri dengan komputer yang dilengkapi program multimedia. Di pasaran banyak beredar software-software edutainment yang memadukan pendidikan dengan hiburan. Beberapa program yang sering dipakai dalam pembelajaran berbasis multimedia dan tidak terlalu sulit mempelajarinya antara lain Power Point, Macromedia Director, Macromedia Flash, Maple, Mathcad, dan Hot Potatoes.

Macromedia Flash MX merupakan software keluaran Macromedia Inc. Software ini merupakan program untuk 
mendesain grafis animasi yang sangat populer dan banyak digunakan desainer grafis. Kelebihan flash terletak pada kemampuannya menghasilkan animasi gerak dan suara. Awal perkembangan flash banyak digunakan untuk animasi pada website, namun saat ini mulai banyak digunakan untuk media pembelajaran karena kelebihan-kelebihan yang dimiliki.

Kelebihan-kelebihan pembelajaran dengan Macromedia Flash MX adalah sebagai berikut:

a. Pembelajaran lebih menarik dan menyenangkan.

b. Dapat menstimulasi efek gerak.

c. Dapat diberi suara dan warna

d. Tidak memerlukan keahlian khusus dalam penyajian.

e. Tidak memerlukan ruang gelap dalam penyajian.

Selain memiliki kelebihan, beberapa kekurangan yang dimiliki oleh media pembelajaran dengan Macromedia Flash MX, adalah sebagai berikut:

a. Memerlukan peralatan khusus dalam penyajian.

b. Memerlukan tenaga listrik.

c. Memerlukan keterampilan khusus dan kerja tim dalam pembuatan. ${ }^{17}$

d. Membutuhkan waktuyang cukup lama untuk menghasilkan CD pembelajaran yang menarik, menyenangkan, dan mencakup semua materi yang akan diajarkan atau disampaikan kepada siswa.

\section{E. E-LEARNING (PEMBELAJARAN BERBASIS WEB) SEBAGAI MEDIA PEMBELAJARAN.}

Istilah e-learning, atau electronic learning, dan sering disebut juga distance learning atau pendidikan jarak jauh. Pendidikan jarak jauh adalah sistem pendidikan yang pelaksanaannya memisahkan guru dan siswa, karena faktor jarak dan waktu. Karena guru dan siswa terpisahkan, maka penyampaian bahan ajar disajikan di

17 http://www.indopos.co.id/index.php?act=cetak\&id=28. Download tanggal 02 April 2017. 
komputer melalui internet dan dalam bentuk media elektronik. Media elektronik yang dimaksud dapat berupa web site dengan berbagai fasilitas seperti chatting, presentasi dan jurnal yang bisa di download, ujian dan penilaian online, forum diskusi virtual, forum konsultasi dan tanya jawab, discussion board, maupun video conference. ${ }^{18}$

Pembelajaran dengan menggunakan media elektronik elearning, seperti juga namanya "Electronic Learning" disampaikan dengan menggunakan media elektronik yang terhubung dengan internet (worldwidewebyang menghubungkan semua unit komputer di seluruh dunia yang terkoneksi dengan internet) dan intranet (jaringan yang bisa menghubungkan semua unit komputer dalam sebuah perusahaan). Jika anda memiliki komputer yang terkoneksi dengan internet, anda sudah bisa berpartisipasi dalam e-learning. Dengan cara ini, jumlah pembelajar yang bisa ikut berpartisipasi bisa jauh lebih besar dari pada cara belajar secara konvensional di ruang kelas. Teknologi ini juga memungkinkan penyampaian pelajaran dengan kualitas yang relatif lebih standar dari pada pembelajaran di kelas yang tergantung pada "mood" dan kondisi fisik dari instruktur. Dalam e-learning, modul-modul yang sama (informasi, penampilan, dan kualitas pembelajaran) bisa diakses dalam bentuk yang sama oleh semua siswa yang mengaksesnya, sedangkan dalam pembelajaran konvensional di kelas, karena alasan kesehatan atau masalah pribadi, satu instruktur pun bisa memberikan pelajaran di beberapa kelas dengan kualitas yang berbeda. ${ }^{19}$

E-learning dalam arti luas bisa mencakup pembelajaran yang dilakukan di media elektronik (internet) baik secara formal maupun informal. E-learning secara formal, misalnya adalah pembelajaran dengan kurikulum, silabus, mata pelajaran dan tes yang telah diatur dan disusun berdasarkan jadwal yang telah disepakati pihak-pihak terkait (pengelola e-learning dan pembelajar sendiri). Pembelajaran seperti ini biasanya tingkat interaksinya tinggi dan diwajibkan oleh perusahaan pada karyawannya, atau pembelajaran jarak jauh yang

18 http://tentangku.blogsome.com/category/iptek/e-learning/. Dan lihat juga di http://www. ummigroup.co.id/annida/?pilih=arsip\&topik=1. Download tanggal 11 April 2017.

19 http://mankendal.wordpress.com/. Download tanggal 03 April 2017. 
dikelola oleh universitas dan perusahaan-perusahaan (biasanya perusahan konsultan) yang memang bergerak di bidang penyediaan jasa e-learning untuk umum. E-learning bisa juga dilakukan secara informal dengan interaksi yang lebih sederhana, misalnya melalui sarana mailing list, e-newsletter atau website pribadi, organisasi dan perusahaan yang ingin mensosialisasikan jasa, program, pengetahuan atau keterampilan tertentu pada masyarakat luas (biasanya tanpa memungut biaya). ${ }^{20}$

E-learning sebagai sebuah wacana baru dirasakan lebih sesuai untuk peserta didik dengan karakteristik tertentu, yaitu yang memiliki pemikiran kritis, telah memiliki cara untuk belajar, memiliki kemampuan untuk mengumpulkan dan menggunakan ilmu pengetahuan yang dimilikinya, dan memiliki kecenderungan untuk terus melanjutkan studi mereka. ${ }^{21}$ Selain itu e-learning juga sesuai dengan karakteristik peserta didik yang hanya memiliki keterbatasan waktu, keterbatasan tempat belajar, keterpisahan jarak secara geografis, dan keinginan peserta didik untuk belajar di tempatnya sendiri. Dengan demikan e-learning telah memperbesar kesempatan bagi individu untuk mendapatkan pendidikan yang diinginkannya sekaligus mempercepat terciptanya masyarakat yang berpengetahuan (knowledge society).

Dengan adanya e-learning memberi banyak keuntungan pada proses pembelajaran terhadap semua pihak yang terkait dengan proses pembelajaran tersebut, seperti memberikan kemudahan bagi guru dan juga siswa.Secara umum dengan adanya e-learning para guru/dosen/instruktur akan lebih mudah dalam hal-hal berikut:

1. Melakukan pemutakhiran bahan-bahan belajar yang menjadi tanggung jawabnya sesuai dengan tuntutan perkembangan keilmuan yang mutakhir

2. Mengembangkan diri atau melakukan penelitian guna meningkatkan wawasannya

20 http://main.man3malang.com/index.php. Download tanggal 28 April 2017.

21 Eti Rochaety, Pontjorini Rahayuningsih, dan Prima Gusti Yanti, Sistem Informasi Manajemen Pendidikan, (Jakarta: PT. Bumi Aksara, 2006), h. 77. 
3. Mengontrol kegiatan belajar peserta didik. ${ }^{22}$

Adapun manfaat e-leraning bagi dunia pendidikan secara umum bisa diklasifikasikan menjadi tiga, yaitu: ${ }^{23}$

1. Fleksibilitas. Jika pembelajaran konvensional di kelas mengharuskan siswa untuk hadir di kelas pada jam-jam tertentu (seringkali jam ini bentrok dengan kegiatan rutin siswa), maka e-learning memberikan fleksibilitas dalam memilih waktu dan tempat untuk mengakses pelajaran.

2. Independent Learning, e-learning memberikan kesempatan bagi pembelajar untuk memegang kendali atas kesuksesan belajar masing-masing, artinya pembelajar diberi kebebasan untuk menentukan kapan akan mulai, kapan akan menyelesaikan, dan bagian mana dalam satu modul yang ingin dipelajarinya terlebih dulu.

3. Biaya, banyak biaya yang bisa dihemat dari cara pembelajaran dengan e-learning.

Selain memberikan banyak keuntungan, e-learning juga mempunyai banyak keterbatasan, Di antara keterbatasan e-learning adalah: ${ }^{24}$

1. Budaya, beberapa orang merasa tidak nyaman mengikuti pelatihan dan pembelajaran melalui komputer.

2. Investasi, walaupun e-learning menghemat banyak biaya, tetapi suatu organisasi harus mengeluarkan investasi awal cukup besar untuk mengimplementasikan e-learning.

3. Teknologi, karena teknologi yang digunakan pada e-learning beragam, ada kemungkinan teknologi tersebut tidak sejalan dengan yang sudah ada dan terjadi konflik teknologi sehingga e-learning tidak berjalan baik.

4. Infrastruktur, internet belum menjangkau semua kota di Indonesia.

22 http://smkn1kutaselatan.wordpress.com/. Dowload tanggal 06 April 2017.

23 http://mankendal.wordpress.com/. Download tanggal 06 April 2017.

24 Empy Effendi dan Hartono Zhuang, E-learning Konsep dan Aplikasi, (Yogyakarta: Penerbit Andi, 2005), h. 15-17. 
5. Materi, tidak semua materi pelajaran dapat diterapkan dengan e-learning, misalnya materi yang menuntut adanya praktek dan bimbingan langsung dari seorang guru.

Penerapan e-learning telah merambah ke berbagai lembaga pendidikan, termasuk lembaga pendidikan Islam. Kemajuan informasi dan teknologi pada lembaga pendidikan Islam, khususnya madrasah, baik madrasah tsanawiyah dan madrasah aliyah telah menunjukkan beberapa kemajuan yang pesat. Di antara madrasah yang telah maju dalam hal teknologi informasi adalah adalah MAN 9 Pondok Kopi Jakarta, ${ }^{25}$ penerapan e-learning pada madrasah ini adalah pada pemberian tugas akhir ujian kelas 3 mata pelajaran TIK, siswa mendapatkan soal ujiannya dengan men-dowload pada web sekolahnya. Madrasah lain yang memiliki fasilitas teknologi informasi yang lengkap adalah MAN 3 Malang, MAN Kendal, dan masih banyak lagi madrasah lainnya.

Menurut hemat penulis, secara umum memang kemajuan informasi teknologi pada madrasah masih pada tahap penyediaan fasilitas dan menyiapkan berbagai infrastruktur lain. Adapun penerapan e-learning yang berbasis web secara umum masih diterapkan pada mata pelajaran tertentu, yakni TIK (Teknologi Informasi dan Komunikasi). Adapun pada materi rumpun pendidikan Islam sendiri penulis belum menemukan adanya aplikasi e-learning yang berbasis web tersebut.

\section{F. KRITERIA PEMILIHAN MEDIA PEMBELAJARAN}

Media yang merupakan salah satu sarana untuk meningkatkan kegiatan proses pembelajaran, dan karena beraneka ragamnya media tersebut, maka masing-masing media mempunyai karakteristik yang berbeda-beda. Untuk itu, perlu memilihnya dengan cermat dan tepat agar dapat digunakan secara tepat guna. Mengkondisikan pembelajaran yang efektif, efisien, dan menyenangkan bagi peserta didik, bukanlah mudah. Untuk mencapai itu, perlu media pembelajaran. Media yang tepat dapat memotivasi siswa untuk

25 http://man9jkt.web.id/web/index.php?option=com_frontpage\&Itemid=1. Download tanggal 11 April 2017. 
meningkatkan prestasi belajarnya.

Memilih media yang terbaik untuk tujuan instruksional bukan pekerjaan yang mudah. Hal ini diakui oleh mereka yang pernah berkecimpung dalam tugas pemilihan media tersebut. Pemilihan itu rumit dan sulit, karena didasarkan pada beberapa faktor yang saling berhubungan, seperti tergambar dalam pertanyaan berikut: ${ }^{26}$

1. Seberapa jauh situasi dan latar pekerjaan yang sebenarnya perlu ditiru dalam program pembelajaran?

2. Media apa yang dianggap paling praktis untuk melaksanakan dan memperbarui program pembelajaran.

3. Apakah diperlukan perlengkapan untuk menggunakan media yang dipilih itu? Jika iya, apakah sudah tersedia, atau apakah pengadaan alat tertentu itu dapat dipertanggungjawabkan untuk keperluan pelajaran yang bersangkutan.

4. Apakah media ini sesuai dengan kebutuhan belajar siswa (ditinjau dari segi kebudayaan, usia, kebiasaan belajar, dan sebagainya), atau malah akan membingungkan mereka.

5. Sejauh manakah pencapaian siswa harus sesuai dengan sasaran yang telah ditentukan.

6. Apakah nilai bahan pelajaran (perubahan tingkah laku yang diharapkan terjadi, jumlah siswa yang ada, atau isi mata pelajaran) sepadan dengan biaya yang dikeluarkan untuk mendapatkan media itu.

Lebih lanjut Ronald H Anderson menyatakan bahwa masalah pemilihan media menjadi rumit karena adanya kecenderungan pada sementara pengembang pelajaran yang beranggapan bahwa pemilihan media adalah suatu fungsi yang terpisah dan berdiri sendiri, yang dilakukan di suatu saat tertentu dalam proses pengembangan pembelajaran. ${ }^{27}$ Pendapat ini timbul sebagai akibat dari usaha menjadikan proses pemilihan media secara mekanis yang paling ilmiah dan paling tepat. Meskipun tujuan akhirnya tampak

26 Ronald H. Anderson, Pemilihan dan Pengembangan Media untuk Pembalajaran, terj. Yusufhadi Miarso, dkk., (Jakarta: PT Raja Grafindo Persada, 1994), h. 1.

27 Ibid., h. 4. 
baik, kenyataannya justru tidak mungkin diperoleh keputusan yang tepat secara ilmiah.. Jadi, sebagai suatu sistem yang menyeluruh, proses teknologi pembelajaran memberikan semacam petunjuk untuk mempertimbangkan semua unsur yang penting dalam pengembangan bahan pelajaran dan media itu diberikan pada saat yang paling tepat.

Dua orang ahli pendidikan dari Perancis Gagul dan Raise, berpendapat dalam menentukan pemilihan media penyampaian pesan tertentu secara umum, ada kaitannya dengan media pembelajaran. Dengan kata lain teknik dan strategi penyampaian informasi yang dilakukan oleh orang pada umumnya di luar pendidikan, pasti akan berlaku juga dalam dunia pendidikan. Pendapat lain mengenai prosedur pemilikan media komunikasi, dikemukakan oleh Anderson. Menurutnya, prosedur pemilihan media dimulai dari pertanyaan; Apakah media tersebut diperuntukan bagi keterampilan fisik atau kognitif. Pertanyaan ini akan menentukan desain seperti apa media pembelajaran tersebut seharusnya dibuat. ${ }^{28}$

Menurut Kemp (1975), karakteristik sebuah media pembelajaran merupakan dasar pemilihan media sesuai dengan situasi belajar tertentu. Dia juga mengatakan, bahwa pengetahuan mengenai kekurangan dan kelebihan tertentu yang dimiliki oleh sebuah media pembelajaran, adalah sesuatu yang sangat penting diketahui oleh para tenaga pendidik.

Proses pembelajaran dapat berlangsung kapan pun dan dimana pun diperlukan. Sikap positif siswa terhadap materi pembelajaran serta proses pembelajaran dapat ditingkatkan. Peran guru harus dapat memilih media mana yang sesuai dengan kondisi dan kebutuhan. Contoh media kaset audio, media auditif yang mengajarkan topik-topik pembelajaran yang bersifat verbal seperti pengucapan bahasa asing. Untuk pengajaran bahasa asing, media ini tepat karena jika pembelajarannya diberikan tanpa media sering terjadi ketidaktepatan dalam pengucapan pengulangan.

Ada beberapa hal yang harus diperhatikan dalam memilih

28 mailto:butar_lbt@yahoo.co.id. Download tanggal 21 Februari 2017. 
media, antara lain: tujuan pembelajaran yang ingin dicapai, ketepatgunaan, kondisi siswa, ketersediaan perangkat keras (hardware) dan perangkat lunak (software), mutu teknis dan biaya. Oleh sebab itu, beberapa pertimbangan yang perlu diperhatikan antara lain: ${ }^{29}$

1. Media yang dipilh hendaknya selaras dan menunjang tujuan pembelajaran yang telah ditetapkan.

2. Aspek materi pembelajaran juga penting untuk dipertimbangkan dalam memilih media.

3. Kondisi siswa yang mencakup faktor umur, intelegensi, latar belakang pendidikan, budaya, dan lingkungan anak menjadi titik perhatian dan pertimbangan dalam memilih media pembelajaran.

4. Ketersediaan media di sekolah atau memungkinkan bagi guru mendesain sendiri media yang akan digunakan merupakan hal yang perlu menjadi pertimbangan seorang guru dalam memilih media pembelajaran.

5. Media yang dipilih hendaknya dapat menjelaskan apa yang akan disampaikan kepada siswa secara tepat dan berhasil guna.

6. Biaya yang akan dikeluarkan dalam pemanfaatan media harus seimbang dengan hasil yang akan dicapai.

Profesor Ely sebagaimana dikutip oleh Arief S. Sadiman, dkk, mengatakan bahwa pemilihan media seyogyanya tidak terlepas dari konteksnya bahwasannya media merupakan komponen dari sistem instruksional secara keseluruhan. Karena itu, meskipun tujuan dan isinya sudah diketahui, faktor-faktor lain seperti karakteristik siswa, strategi belajar mengajar, organisasi kelompok belajar, alokasi waktu dan sumber, serta prosedur penilaiannya juga perlu dipertimbangkan. ${ }^{30}$ Sebagai pendekatan praktis maka disarankan untuk mempertimbangkan media apa saja yang ada, berapa harganya, berapa lama diperlukan untuk mendapatkannya,

29 Asnawir dan Basyiruddin..., Media..., h. 15-16.

30 Arief S. Sadiman, dkk, Media Pendidikan Pengertian, Pengembangan dan Pemanfaatannya (Jakarta: PT Raja Grafindo Persada, 1996), h. 85. 
dan format apa yang memenuhi selera pemakai, misalnya siswa dan guru.

Dalam hubungan ini Dick dan Carey, sebagaimana dikutip oleh Arief S. Sadiman, dkk, menyebutkan bahwa di samping kesesuaian dengan tujuan perilaku belajarnya, setidaknya masih ada empat faktor lagi yang perlu dipertimbangkan dalam pemilihan media, yaitu: ${ }^{31}$ (a) ketersediaan sumber setempat, artinya bila sumber media tidak terdapat pada sumber-sumber yang ada, maka harus dibeli atau dibuat sendiri. (b) Ketersediaan dana, tenaga, dan fasilitas yang digunakan untuk membeli atu memproduksi sendiri, (c) faktor yang menyangkut keluwesan, kepraktisan, dan ketahanan media yang bersangkutan untuk waktu yang lama, artinya bisa digunakan di manapun dengan peralatan yang ada di sekitarnya dan kapanpun serta mudah dijinjing dan dipindahkan, (d) efektifitas biaya dalam jangka waktu yang panjang, sebab ada jenis media yang biaya produksinya mahal, namun bila dilihat kestabilan materinya dan penggunaanya yang berulang-ulang untuk jangka waktu yang panjang mungkin lebih murah dibanding media yang biaya produksinya lebih murah tetapi setiap waktu materinya berganti. Hakikat dari pemilihan media ini pada akhirnya adalah keputusan untuk memakai, tidak memakai, atau mengadaptasi media yang bersangkutan.

Untuk menciptakan pembelajaran yang tidak membosankan dan tidak monoton, maka seorang guru dituntut untuk bisa menvariasikan media pembelajaran yang akan digunakan agar pembelajaran lebih efektif dan efisien. Variasi media belajar yang dimaksudkan adalah penggunaan media secara bervariasi antara jenis-jenis media belajar yang ada. Akan tetapi penggunaannya tidak lepas dari pertimbangan tujuan belajar yang akan dicapai. Begitu pula, penggunaan media dimungkinkan secara serempak dua atau tiga jenis media sekaligus dalam satuan pengajaran tertentu.

Variasi penggunaan media dan bahan pembelajaran yang dapat dilihat, didengar, atau diraba dan dimanipulasi dalam proses

31 Ibid., h. 86. 
pembelajaran menjadi sangat penting. Alasannya antara lain:

1. Guru dapat menggunakan variasi media dan bahan pembelajaran yang dapat dilihat seperti menggunakan sketsa, gambar, grafik, film, foto, penayangan TV, video, dan komputer.

2. Penggunaan variasi media dan bahan pembelajaran yang dapat didengar seperti rekaman suara guru dan suara murid akan lebih menghidupkan suasana pembelajaran sehingga perhatian siswa bisa terpusat pada pembelajaran.

3. Penggunaan variasi media dan bahan pembelajaran yang dapat diraba dan dimanipulasi seperti tiruan benda, pengalaman langsung, dan sebagainya. ${ }^{32}$

Selanjutnya langkah-langkah dalam pemilihan dan pengembangan media pembelajaran adalah sebagai berikut: ${ }^{33}$

1. Analisis tugas, dalam hal ini seorang guru harus bisa memahamkan siswa tentang tugas-tugasnya dalam pembelajaran.

2. Menyiapkan tujuan dan tes.

3. Memperbaiki dan menyusun tujuan, memilih media, mendesain dan menyiapkan bahan-bahan..

4. Menguji bahan pelajaran dan mengadakan perbaikan seperlunya pada isi pelajaran dan media.

5. Menyajikan latihan, dengan latihan ini akan terlihat hasil yang dicapai oleh siswa.

Inti dari penggunaan variasi pembelajaran dan pengembangannnya adalah untuk menciptakan pembelajaran yang aktif, kreatif, efektif, menarik, dan menyenangkan, Sehingga memudahkan untuk mencapai tujuan pembelajaran.

32 Siti Kusrini.dkk Ketrampilan Dasar Mengajar..., h. 112.

33 Ronald Anderson, Pemilihan..., h. 8-12. 


\section{G. TEKNOLOGI PENDIDIKAN DAN MEDIA PEMBELAJARAN YANG TEPAT DITERAPKAN PADA SEKOLAH}

Sebagaimana telah dibahas sebelumnya bahwa perkembangan teknologi mempunyai pengaruh yang besar terhadap perkembangan media pembelajaran. Teknologi baru, terutama multimedia mempunyai peranan semakin penting dalam proses pembelajaran. Banyak orang percaya bahwa multimedia akan dapat membawa kita kepada situasi belajar dimana learning with effort akan dapat digantikan dengan learning with fun. Jadi proses pembelajaran yang menyenangkan, kreatif, tidak membosankan akan menjadi pilihan tepat bagi para guru.

Pada kenyataannya bahwa saat ini Indonesia memasuki era informasi yaitu suatu era yang ditandai dengan makin banyaknya medium informasi, tersebarnya informasi yang makin meluas dan seketika, serta informasi dalam berbagai bentuk yang bervariasi tersaji dalam waktu yang cepat. Penyajian pesan pada era informasi ini akan selalu menggunakan media, baik elektronik maupun non elektronik. Terkaitdengankehadiranmediaini, Dimyati menjelaskan bahwa suatu media yang terorganisasi secara rapi mempengaruhi secara sistematis lembaga-lembaga pendidikan seperti lembaga keluarga, agama, sekolah, dan pramuka. Dari uraian tesebut menunjukkan bahwa kehadiran media telah mempengaruhi seluruh aspek kehidupan, termasuk sistem pendidikan kita, meskipun dalam derajat yang berbeda-beda. ${ }^{34}$

Peran guru harus dapat memilih media mana yang sesuai dengan kondisi dan kebutuhan. Contoh media kaset audio, media auditif yang mengajarkan topik-topik pembelajaran yang bersifat verbal seperti pengucapan bahasa asing. Untuk pengajaran bahasa asing, media ini tepat karena jika pembelajarannya diberikan tanpa media sering terjadi ketidaktepatan dalam pengucapan pengulangan. ${ }^{35}$

34 http://wiki.poltekkes-pdg.ac.id/index.php? title=Tinjauan_eLearning \#column-one. Download tanggal 16 Maret 2017.

35 http://www.equator-news.com/. Download tanggal 06 Maret 2017. 
Adapun penerapan media pada suatu sekolah harus dilihat berbagai faktor yang mempengaruhinya. Misalnya suatu sekolah dapat menerapkan dengan pembelajaran e-learning dengan baik, karena didukung fasilitas yang lengkap, guru yang kompeten dalam bidang teknologi, namun lain halnya dengan sekolah lain yang masih menghadapi banyak kendala dalam menerapkan e-learning, maka jelas sekolah tersebut harus mempersiapkan banyak hal dalam menerapkannya.

Sebagaimana telah dijelaskan di atas, bahwa dalam pemilihan dan pengembangan media harus mempertimbangkan berbagai faktor. Beberapa kriteria dalam pemilihan media pembelajaran yang tepat pada suatu lembaga pendidikan; (a) ketersediaan sumber setempat, (b) tersedia dana, tenaga, dan fasilitas, (c) keluwesan, kepraktisan, dan ketahanan media dalam waktu yang lama, (d) efektititas dan efisiensi biaya dalam jangka waktu yang cukup panjang. ${ }^{36}$ Menurut hemat penulis, untuk membahas penerapan media yang tepat pada sekolah, khususnya untuk Sekolah Menengah Umum ataupun Madrasah Aliyah. perlu adanya pemilahan atau pengklasifikasian terhadap sekolah-sekolah, karena tidak semua sekolah mempunyai peralatan teknologi yang sama dengan sekolah yang lainnya. Pengklasifikasian sekolah atau madrasah adalah sebagai berikut:

1. Sekolah dengan fasilitas teknologi yang belum memadai

Sekolah yang belum memiliki fasilitas teknologi yang lengkap, misalnya ketersediaan komputer yang masih sangat terbatas, maka menurut hemat penulis sekolah tersebut lebih tepat menggunakan media pembelajaran yang tidak menuntut banyak penggunaan teknologi, seperti dengan menggunakan media cetak (buku, majalah, hand out), media audio (radio dan tape recorder), media visual yang konvensional dan seorang guru dituntut untuk lebih mengkreasikan dengan penggunaan strategi pembelajaran aktif, sehingga pembelajaran lebih menarik dan bermakna bagi siswa. Namun dalam sekolah tersebut harus segera mengupayakan untuk melengkapi fasilitas

36 Asnawir dan Basyiruddi Usman, Media..., h. 126. 
teknologi sehingga model pembelajaran dapat ditingkatkan. Lebih-lebih dengan masuknya mata pelajaran Teknologi Informasi dan Komunikasi (TIK) dalam kurikulum, maka sekolah mau tidak mau harus melengkapi fasilitas teknologi, misalnya dengan penyediaan komputer yang memadai untuk praktek. Hal ini disebabkan karena mata pelajaran TIK adalah mata pelajaran yang menuntut praktek langsung, bukan sekedar teori yang dipelajari dari buku panduan.

Keunggulan dan kemudahan pembelajaran konvensional adalah sebagai berikut:

a. Masih kentalnya hubungan guru dan murid, sehingga guru bisa menyampaikan nilai-nilai moral yang merupakan tujuan penting dari proses pendidikan, yaitu terbentuknya peserta didik yang berakhlak mulia dan berkepribadian luhur, mengingat usia anak pada masa SMU/MA secara psikologis merupakan masa perkembangan yang mengalami beberapa gejala emosional dan memerlukan adanya sentuhan nilai-nilai moral yang diajarkan oleh seorang guru.

b. Tidak memerlukan banyak biaya, biaya untuk pengadaan fasilitas yang mendukung pembelajaran relatif murah.

Kelemahan pembelajaran konvensional adalah:

c. Pembelajaran harus di dalam kelas dan menuntut hadirnya seorang guru.

d. Pembelajaran harus dilakukan bersama dan tidak dapat dilakukan secara individual.

e. Terbatasnya referensi dan sumber, hal ini tergantung pada kreativitas seorang guru untuk menggali informasi dari multisumber.

Melihat keunggulan/ kemudahan serta kelemahan pembelajaran konvesional, maka pengadaan fasilitas dan peningkatan kualitas kompetensi guru merupakan dua hal penting yang harus diperhatikan dan diupayakan pada sekolah 
yang belum mempunyai dan menerapkan teknologi secara maksimal dalam pembelajaran. Bagi pemerintah, hendaknya harus memperhatikan sekolah-sekolah yang belum mempunyai fasilitas teknologi dengan memberikan bantuan kepada sekolah tersebut. Bagi pihak sekolah, hendaknya juga proaktif dengan kemajuan teknologi informasi dan mengupayakan dengan semaksimal mungkin untuk mengikuti perkembangan teknologi baik dengan pengadaan fasilitas maupun dengan meningkatkan kualitas tenaga kependidikan. Hal ini jelas bertujuan untuk membentuk peserta didik yang melek teknologi dan mampu mengikuti perkembangan teknologi dalam dunia global yang semakin pesat.

2. Sekolah dengan fasilitas yang memadai

Sekolah dengan fasilitias teknologi yang memadai, misalnya memiliki laboratorium komputer yang lengkap, komputer yang online dengan internet, mempunyai $L C D$ Projector, dan peralatan teknologi yang lainnya, serta didukung oleh tenaga yang kompeten dalam bidang teknologi, maka media pembelajaran atau teknologi pendidikan yang tepat untuk sekolah seperti ini adalah dengan e-learning dan pembelajaran dengan multimedia. Karena dengan adanya sarana dan prasarana yang mendukung tidak menjadi halangan bagi sekolah tersebut untuk menerapkan pembelajaran yang modern dan online dengan internet.

Keunggulan dan kemudahan pembelajaran dengan internet (e-learning) adalah sebagai berikut:

a. Dapat dilakukan secara individual.

b. Informasi cepat diperoleh.

c. Dapat dilakukan di mana saja.

d. Dapat dilakukan di sembarang waktu.

e. Tersedia aneka referensi dari multisumber.

f. Tersedia informasi terkini.

g. Tersedia informasi tak terbatas.

h. Referensi dapat didokumentasi secara elektronik dan tertulis. 
i. Mudah berkomunikasi antar pembelajar secara global. ${ }^{37}$

Adapun kekurangan dan kesulitan pembelajaran dengan internet adalah sebagai berikut:

a. Menuntut perangkat keras yang memadai.

b. Menuntut jaringan komunikasi yang memadai.

c. Pembelajar harus melek teknologi.

d. Pembelajar harus menguasai bahasa internet.

e. Memerlukan biaya (cost) yang relatif tinggi.

f. Sulit menanamkan nilai-nilai moral.

g. Sulit mengontrol informasi yang menyesatkan. ${ }^{38}$

Melihat adanya banyak keunggulan dan kemudahan pembelajaran dengan model e-learning, maka model pembelajaran ini baik untuk diterapkan dengan syarat tersedianya sarana dan prasarana yang mendukung serta guru dan siswa yang melek teknologi. Untuk mengantisipasi kendalakendala yang dihadapi seperti sulitnya mengontrol informasi yang menyesatkan dan sulitnya menanamkan nilai-nilai moral, maka tetap diperlukan pembelajaran dengan tatap muka dalam kelas. Misalnya, untuk materi pembelajaran tertentu seorang siswa harus belajar menggunakan media internet pada minggu pertama, untuk minggu kedua dengan mengadakan pembelajaran tatap muka di dalam kelas untuk menyampaikan hal-hal yang memerlukan keterangan lebih lanjut serta untuk menanamkan nilai-nilai moral yang bisa berguna bagi siswa. Jadi, pembelajaran konvensional dengan tatap muka di dalam kelas tetap diperlukan, sesuai dengan kebutuhan, situasi, dan kondisi yang ada. Karena tujuan penggunaan internet sebagai media dan sumber pembelajaran adalah untuk meningkatkan kemampuan siswa agar belajar lebih baik dan meningkatkan performan mereka sesuai tujuan yang ingin dicapai.

37 Ki Supriyoko, “Teknologi Pendidikan Agama Islam”, Makalah disampaikan dalam Seminar di UIN Sunan Kalijaga Yogyakarta pada tanggal 28 April 2016.

38 Ibid. 


\section{H. KESIMPULAN}

Media pembelajaran merupakan sesuatu yang dapat menyalurkan pesan, merangsang pikiran, perasaan, dan kemauan audien (siswa) sehingga dapat mendorong proses belajar pada dirinya. Penggunaan media secara kreatif akan memungkinkan tumbuhnya kesadaran belajar siswa dan dapat meningkatkan performan mereka sesuai dengan tujuan yang ingin dicapai.

Dari segi karakternya, terdapat beberapa macam media pembelajaran, yaitu: media audio, media visual, media audiovisual, dan media cetak. Kemajuan teknologi informasi sangat memungkinkan untuk menerapkan teknologi tersebut dalam pendidikan, baik dengan menerapkannya sebagai media pembelajaran seperti penerapana multimedia dalam pembelajaran, serta pembelajaran jarak jauh (distance learning) atau pembelajaran dengan mengakses dari internet (e-learning).[]

\section{DAFTAR PUSTAKA}

Anderson, Ronald H. Pemilihan dan Pengembangan Media untuk Pembalajaran, terj. Yusufhadi Miarso, dkk, Jakarta: PT Raja Grafindo Persada, 1994.

Arsyad, Azhar, Media Pembelajaran, Jakarta: PT Raja Grafindo Persada, 2007.

Asnawir dan Basyiruddin Usman, Media Pembelajaran, Jakarta: Ciputat Press, 2002.

Effendi, Empy dan Zhuang, Hartono, E-learning Konsep dan Aplikasi, Yogyakarta: Penerbit Andi, 2005.

Eti, Rochaety, Rahayuningsih, Pontjorini dan Yanti, Prima Gusti, Sistem Informasi Manajemen Pendidikan, Jakarta: PT. Bumi 
Aksara, 2006.

Hamalik, Oemar, Media Pendidikan, Bandung: PT Citra Aditya, 1994.

Kusrini,.Siti dkk Ketrampilan Dasar Mengajar (PPL I) Berorientasi Pada Kurikulum Berbasis Kompetensi, Malang: Fakultas Tarbiyah Universitas Islam Negeri, 2005.

Miarso, Yusufhadi. Menyemai Benih Teknologi Pendidikan, Jakarta: Kencana, 2007.

Prawiradilaga, Dewi Salma dan Siregar, Eveline. ed, Mozaik Teknologi Pendidikan, Jakarta: Kencana, 2007.

Rohani HM, Ahmad, Media Instruksional Edukatif, Jakarta: PT Rineka Cipta, 1997.

Sadiman, Arief S. dkk, Media Pendidikan Pengertian, Pengembangan dan Pemanfaatannya, Jakarta: PT Raja Grafindo Persada, 1996.

Sudjana, Nana dan Rivai, Ahmad, Media Pengajaran, Bandung: Sinar Baru Algesindo, 2005.

Yunus, Mahmud, Al-Tarbiyah wa al-Ta'liem, Padang Panjang: Matbah, 1942.

http://www.equator-news.com/.

http://www.blog.tp-unj.org/index.php.

http://www.indopos.co.id/index.php.

mailto:butar_lbt@yahoo.co.id.

http://tentangku.blogsome.com/category/iptek/e-learning/. 